\title{
Human T lymphotropic virus type I (HTLV-I) infection in neurological patients in Salvador, Bahia, Brazil
}

\author{
Irênio Gomes ${ }^{\mathrm{a}}$, Ailton Melo ${ }^{\mathrm{b}}$, Fernando A. Proietti ${ }^{\mathrm{c}}$, Otavio Moreno-Carvalho ${ }^{\mathrm{d}}$, \\ Luiz Antonio M. Loures ${ }^{\mathrm{e}}$, Marie Christine Dazza ${ }^{\mathrm{g}}$, Gerard Said ${ }^{\mathrm{f}}$, \\ Bernard Larouzé ${ }^{\mathrm{g}}$, Bernardo Galvão-Castro ${ }^{\mathrm{a}, *}$ \\ ${ }^{a}$ Laboratório Avançado de Saúde Pública, CPqGM, Fundação Oswaldo Cruz, Salvador, Bahia, Brazil \\ ${ }^{\mathrm{b}}$ Departamento de Neuro-Psiquiatria, Universidade Federal da Bahia, Salvador, BA, Brazil \\ ${ }^{\mathrm{c}}$ Departamento de Medicina Preventiva e Social, Universidade Federal de Minas Gerais, Belo Horizonte, MG, Brazil \\ ${ }^{\mathrm{d}}$ Laboratório de Líquor, Fundação José Silveira, Salvador, BA, Brazil \\ ${ }^{\mathrm{e}}$ National Program of STD/AIDS, Ministry of Health, Brasilia, DF, Brazil \\ ${ }^{\mathrm{f}}$ Service de Neurologie, Hôpital du Kremlin-Bicêtre, Kremlin Bicêtre, Paris, France \\ ${ }^{\mathrm{g}}$ Institut de Medecine et d'Epidemiologie Tropicales, Faculté Xavier Bichat, Paris, France
}

Received 8 September 1998; received in revised form 24 March 1999; accepted 29 March 1999

\begin{abstract}
HTLV-I infection represents a major health concern in endemic areas throughout the world, such as Salvador, the main city of Bahia State, with socio-demographic characteristics similar to sub-Saharan African cities, located in the Northeast of Brazil. In order to provide an estimate of the frequency distribution, and range of neurological manifestations potentially related to HTLV-I infection in this city, we conducted a cross-sectional clinical-epidemiological study to determine the prevalence of this infection in patients with neurological diseases. Patients exhibiting vascular diseases, tumoral diseases or trauma were excluded. Over a period of 16 months, we studied 322 consecutive patients with chronic neurological diseases, who attended the neurological clinics of two major hospitals in Salvador. Overall, the prevalence of HTLV-I infection among the patients was $20.9 \%(67 / 320)$. However, the prevalence among the 104 patients with chronic myelopathy was $50.0 \%$ (52/104). It was observed that the major prevalence of HTLV-I was between the ages of 40 and 60 years with a female predominance. Our data indicate that, in Salvador city, HTLV-I is associated with chronic myelopathies or myeloneuropathies, which seem to be the only neurological diseases associated with HTLV-I. C) 1999 Elsevier Science B.V. All rights reserved.
\end{abstract}

Keywords: HTLV-I; Neurological diseases; TSP; HAM; Prevalence; South America

\section{Introduction}

HTLV-I infection is endemic in Southeast Japan, the Caribbean basin, parts of Africa, and South and Central America [1]. In Brazil, data from eligible and otherwise healthy blood donors showed a nationwide distribution ranging from $0.08 \%$ in the Southern and Northern regions, to $1.35 \%$ in Salvador, the capital and main city of the State

*Corresponding author. of Bahia, located in the Northeast of Brazil [2]. Infectious myelopathies have been described in Brazil, associated with endemic diseases, primarily schistosomiasis, tuberculosis, and cysticercosis [3]. Other causes of inflammatory myelopathies such as multiple sclerosis, myelitis due to syphilis, and those related to HIV-1, are observed in Brazil. In 1985, the association of HTLV-I with Tropical Spastic Paraparesis (TSP) was first demonstrated in Martinica [4]. Later on, cases of similar myelopathy in Southern Japan were reported and called HTLV-I associated myelopathy (HAM) [5]. Since then, HAM/TSP cases 
have been diagnosed all over Brazil but the frequency of this disease among chronic myelopathies varies from 14.7 to $57 \%$ in different published manuscripts [6].

Previous reports have shown the association between HTLV-I and other diseases including neurological syndromes. However the majority are case reports, or case series that sometimes relate HTLV-I infection to uveitis [7], optic neuritis [8], idiopathic Parkinson [9], amyotrophic lateral sclerosis [10], Guillain-Barré syndrome [11], inclusion body myositis and polimiositis [12,13], Central nervous system (CNS) vasculitis [14] and multiple sclerosis [15]. Furthermore, few hospital-based clinicalepidemiological studies with specific pre-tested protocols to determine which neurological syndromes are associated with HTLV-I infection have been reported. In addition, Salvador city presents the highest prevalence of HAM/ TSP in Brazil [16], as well as multiple parasitic and neurological diseases. However, until now, only 4 out of 14 patients from Salvador with myelopathy were typed as HTLV-I [17].

In order to determine and quantify HTLV-I prevalence among patients with several neurological diseases as well as HTLV-I association with any specific neurological disease, we conducted a cross-sectional clinical-epidemiological study in Salvador, Brazil.

\section{Patients and methods}

Salvador, the capital and main city of Bahia State, with approximately 2200000 inhabitants, is located on the Atlantic coast of Northeastern Brazil. Its population is primarily black and mulatto of African and Portuguese descent [18]. From July 1993 to December 1994, all consecutive first time patients attending the neurological clinics of two major hospitals in Salvador (Santo Antônio and Prof. Edgar Santos University Hospitals) were enrolled in the study. The two hospitals are attended primarily by individuals belonging to Bahia State's lower income and poor population strata. It is possible these hospitals serve as the only health facilities available to these patients. Both hospitals are also the primary sites for treatment of myelopathies in the state.

The study was restricted to patients older than 18 years of age. After informed signed consent, patients were submitted to pre-tested epidemiological and clinical questionnaires. The epidemiological questionnaire elicited information pertaining to demographic, socio-economic variables, and known risk factors for HTLV infection. According to skin tone, eye color, nose morphology, lip width, and hair texture, participants were classified into five groups: black, light mulatto, medium mulatto, dark mulatto, and white [19]. The clinical questionnaire emphasized signs and symptoms associated with neurological diseases. Following the questionnaires, the patients were examined by neurologists who established the patients' syndromes and topographical level of patient lesions. Finally, patients with a diagnosis of trauma, vascular, or tumoral diseases were excluded. Exclusion was based on clinical history, neurological examination, appropriate investigations including neuroimaging such as computerized tomography (CT) scan and/or magnetic resonance imaging (MRI), as well as cerebral spinal fluid (CSF) examination and routine blood tests.

Three hundred and seventy seven patients were considered eligible for the study. Patients with signs of myelopathy were submitted to MRI or myelography, according to the level of lesions. The peripheral neuropathy was confirmed by electromyelography (EMG) findings in most patients. CSF examinations were performed on all patients with unidentified peripheral neuropathy or myelopathy, and on those suspected of central nervous system infection. After blood processing, sera were frozen and stored at $-20^{\circ} \mathrm{C}$ until use.

\subsection{Serological assays}

All sera were screened for the presence of antibodies against Human T Lymphotropic Virus I/II (HTLV-I/II) by ELISA (Platelia, Paris, France). Repeatedly reactive samples were then submitted to serological confirmation and discrimination between HTLV-I and HTLV-II using Western blot analysis (HTLV Blot 2.4, Genelabs, Singapore). Western blot results were interpreted according to manufacturer's instructions: (a) HTLV-I positive - reactivity to GAG p19 with or without p24 and two ENV (GD21 and rgp 46-I); (b) HTLV-II positive - reactivity to GAG p24 with or without p19 and two ENV (GD21 and rgp46-II); (c) HTLV positive - reactivity to GAG p19 and p24 and ENV GD21; (d) Indeterminate - HTLV specific bands detected, but not meeting the criteria for HTLV-I, HTLV-II, or HTLV seropositive and (e) HTLV negative - no reactivity to HTLV specific bands.

Sera was also screened for the presence of antibodies against Human Immunodeficiency Virus type 1 and 2 (HIV1/HIV2) by ELISA (Cambridge Biotech Corporation, Worchester, USA). Repeatedly reactive samples were confirmed by Western blot analysis (Biotech Corporation, USA). According to the Western blot results, samples were considered positive when reactivity against env (gp160, gp120 or gp41) and gag (p24) were present. Sera showing no reactivity to HIV specific proteins were considered negative. Samples showing different profiles were considered indeterminate.

Presence of Treponema pallidum infection was screened using non-treponemal cardiolipin antigen (VDRL). VDRL positive samples were further confirmed by $T$. pallidum indirect immunofluorescence assay (FTAbs, Hoeschst Behring, Germany). Samples reactive to both VDRL and FTAbs were considered positive. 


\subsection{CSF examination}

This assay was performed as described previously [20]. Briefly, besides the usual cytology, biochemistry and microbiological evaluation, all CSF were also tested for syphilis, toxoplasmosis, schistosomiasis and cysticercosis specific antibodies by hemaglutination and immunofluorescent reactions, as well as VDRL.

\subsection{Statistical analysis}

Data entry on magnetic media was done using EPINFO 6.02. Prevalence were expressed with their $95 \%$ confidence interval. Data analysis was performed by using variance analysis, Chi Square and Fisher exact tests. In addition, the magnitude of associations was determined and quantified with Odds Ratio (OR) and 95\% confidence interval (CI).

\section{Results}

Clinical and/or epidemiological information was incomplete, or blood samples were not available for 55 (14\%) of 377 eligible patients, thus these patients were excluded from further analysis. Of the 322 remaining patients, 80 $(42.8 \%)$ were ELISA repeatedly reactive and 67 (20.8\%) and $1(0.3 \%)$ were confirmed and discriminated by Western blot as HTLV-I and HTLV-II, respectively. Two samples were indeterminate. The patient positive for HTLV-II is a woman from Chile. She has been living in Bahia since 1976 and she presented a clinical picture of conus medullaris/cauda equina syndrome in 1978. At present she has a non-evolutive flaccid paraparesis with a CSF without abnormalities. No risk factors for HTLV infection were identified.

Frequency distribution of HTLV-I serology according to selected variables is shown in Table 1 . When compared to the HTLV-I seronegative group, the HTLV-I seropositive individuals were more likely to be female and older, primarily between 40 and 60 years old. No association was found with race, place of birth, educational level, history of blood and/or blood product transfusion, or working in health facilities in the past. Although for the variable place of birth, missing information may have introduced a bias in the data analysis and interpretation. Three male participants reported homosexual behavior, 3 women informed past history of prostitution, and 5 ( 4 male and 1 female) reported past history of intravenous drug use.

HTLV-I seroprevalence according to neurological disease is shown in Table 2. Most of the HTLV-I seropositive patients (52 out of $67 ; 77.6 \%$ ) had some type of chronic myelopathy. Among the 104 patients with chronic myelopathy the prevalence of HTLV-I infection was 50\%, with a female predominance as compared to male cases $\left(\chi^{2}=17.12, P<0.001\right)$. Only 15 out of $218(6.9 \%)$ patients with other neurological diseases were infected by HTLV-I.
Table 1

Univariate analysis of HTLV-I serology according to selected demographic variables, for 320 neurological patients in Salvador, Bahia

\begin{tabular}{|c|c|c|c|c|}
\hline \multirow[t]{2}{*}{ Variables } & \multicolumn{2}{|l|}{ HTLV-I } & \multirow[t]{2}{*}{$\mathrm{OR}^{\mathrm{a}}$} & \multirow[t]{2}{*}{$95 \% \mathrm{CI}$} \\
\hline & $\begin{array}{l}\text { POS } \\
\text { n }(\%)\end{array}$ & $\begin{array}{l}\text { NEG } \\
\mathrm{n}(\%)\end{array}$ & & \\
\hline \multicolumn{5}{|l|}{$\operatorname{Sex}$} \\
\hline Male & $26(38.8)$ & $176(69.6)$ & 1.00 & \\
\hline Female & $41(61.2)$ & 77 (30.4) & 3.60 & $1.99-6.56$ \\
\hline \multicolumn{5}{|l|}{ Race } \\
\hline White & $15(23.4)$ & $45(18.6)$ & 1.00 & \\
\hline Mulatto $^{\mathrm{b}}$ & $42(65.6)$ & $158(65.3)$ & 0.80 & $0.39-1.66$ \\
\hline Black & $7(11.0)$ & $39(16.1)$ & 0.54 & $0.18-1.60$ \\
\hline \multicolumn{5}{|l|}{ Age (years) } \\
\hline $18-30$ & $5(7.5)$ & $56(22.1)$ & 1.00 & \\
\hline $31-40$ & $5(7.5)$ & $61(24.1)$ & 0.92 & $0.20-4.22$ \\
\hline $41-50$ & $25(37.3)$ & $48(19.0)$ & 5.83 & $1.96-20.78$ \\
\hline $51-60$ & $17(25.3)$ & $31(12.3)$ & 6.14 & $1.90-23.00$ \\
\hline$>60$ & $15(22.4)$ & $57(22.5)$ & 2.95 & $0.93-10.99$ \\
\hline \multicolumn{5}{|l|}{ Place of Birth } \\
\hline Other City of Bahia State & $21(56.8)$ & $118(69.4)$ & 1.00 & \\
\hline Salvador & $13(35.1)$ & $44(25.9)$ & 1.66 & $0.71-3.84$ \\
\hline Other State & $3(8.1)$ & $8(4.7)$ & 2.11 & $0.33-9.68$ \\
\hline \multicolumn{5}{|l|}{ Education levels (years) } \\
\hline$\leq 4$ & $52(82.5)$ & $217(88.2)$ & 1.00 & \\
\hline $5-11$ & $7(11.1)$ & $24(9.8)$ & 1.22 & $0.45-3.18$ \\
\hline$>11$ & $4(6.4)$ & $5(2.0)$ & 3.34 & $0.64-16.02$ \\
\hline \multicolumn{5}{|l|}{ Blood transfusion } \\
\hline Never & $55(85.9)$ & $216(87.1)$ & 1.00 & \\
\hline$\geq 1$ & $9(14.1)$ & $32(12.9)$ & 1.10 & $0.46-2.59$ \\
\hline \multicolumn{5}{|l|}{ Health Facility worker } \\
\hline No & $59(92.2)$ & $236(95.2)$ & 1.00 & \\
\hline Yes & $5(7.8)$ & $12(4.8)$ & 1.67 & $0.44-5.32$ \\
\hline
\end{tabular}

In these HAM/TSP subjects, $59.6 \%$ were between 40 and 60 years old, and the mean age was $51.1 \pm 11.2$ years. In this group there was no statistically significant difference between the mean age of men when compared with that of women $(t=0.24 ; P=0.80)$. In addition, no age difference was observed between the HAM/TSP group and the HTLV-I positive patients with other neurological diseases $(t=0.21 ; P=0.83)$. In HAM/TSP patients, disease duration ranged from 10 months to 20 years (mean $=5.2 \pm 3.8$ years). Neurological involvement of HAM/TSP patients is shown in Table 3. Peripheral neuropathy was found in $88.5 \%$ of these patients and was characterized by symmetric atrophy in lower limbs, primarily quadriceps sural muscle, and decreased patellar or achileus reflex. Seventeen patients had signs of cerebellar involvement characterized by nistagmus and/or altered coordination tests, but the MRI did not show specific involvement of rombencefalus.

The overall prevalence of HIV-1 and T. pallidum antibodies were $5.2 \%$ (16 out of 305) and $1.3 \%$ (4 out of 
Table 2

HTLV-I seroprevalence among 320 neurological patients

\begin{tabular}{|c|c|c|c|c|}
\hline Pathology & No. of patients & $\begin{array}{l}\text { HTLV-I } \\
\text { Abs positive }\end{array}$ & $\begin{array}{l}\text { Prevalence } \\
\%\end{array}$ & $95 \% \mathrm{CI}$ \\
\hline \multicolumn{5}{|l|}{ Peripheral neuropathies } \\
\hline Unidentified etiology & 30 & 1 & 3.3 & $0.2-19.1$ \\
\hline Alcohol & 25 & 1 & 4.0 & $0.2-22.3$ \\
\hline D. mellitus & 23 & 3 & 13.0 & $3.4-34.7$ \\
\hline HIV & 04 & 1 & 25.0 & $1.3-78.1$ \\
\hline Others $^{\mathrm{a}}$ & 37 & 0 & 0.0 & $0.0-11.7$ \\
\hline Total & 119 & 6 & 5.0 & $2.1-11.1$ \\
\hline \multicolumn{5}{|c|}{ Acute or subacute myelopathy/myeloneuropathy } \\
\hline Unidentified etiology & 13 & 3 & 23.1 & $6.2-54.0$ \\
\hline Toxoplasmosis & 1 & 1 & 100 & $5.5-100$ \\
\hline Others $^{\mathrm{b}}$ & 22 & 0 & 0.0 & $0.0-18.5$ \\
\hline Total & 36 & 4 & 11.1 & $3.6-27.0$ \\
\hline \multicolumn{5}{|c|}{ Chronic myelopathy/myeloneuropathy } \\
\hline Unidentified etiology & 94 & 52 & 55.3 & $44.7-65.5$ \\
\hline Others $^{c}$ & 10 & 0 & 0.0 & $0.0-34.5$ \\
\hline Total & 104 & 52 & 50.0 & $40.1-59.9$ \\
\hline \multicolumn{5}{|l|}{ Extrapiramidal syndrome } \\
\hline Parkinson disease & 7 & 1 & 14.3 & $0.8-58.0$ \\
\hline Dystonia & 1 & 1 & 100 & $5.5-100$ \\
\hline Others $^{\mathrm{d}}$ & 2 & 0 & 0.0 & $0.0-80.2$ \\
\hline Total & 10 & 2 & 20.0 & $3.5-55.8$ \\
\hline \multicolumn{5}{|l|}{ Dementias } \\
\hline Unidentified etiology & 9 & 1 & 11.1 & $0.6-49.3$ \\
\hline Wernicke disease & 22 & 2 & 9.1 & $1.6-30.6$ \\
\hline Alcohol & 7 & 0 & 0.0 & $0.0-43.9$ \\
\hline Total & 38 & 3 & 7.9 & $2.1-22.5$ \\
\hline Others $^{\mathrm{e}}$ & 13 & 0 & 0.0 & $0.0-28.3$ \\
\hline Total & 320 & 67 & 20.9 & $16.7-25.9$ \\
\hline
\end{tabular}

a Alcohol and D. mellitus (7), Guillain-Barré syndrome (14), CIPD (4), Hansen's disease (4), Bell's paralysis (1), cranial nerves' injuries (5), cervical spine osteoarthropathy (1), labyrintopathy (1).

${ }^{\mathrm{b}}$ Transverse myelitis (4), ANM (2), Conus medularis/cauda equina (9, 4 out 9 with Schistosomiasis positive reaction in CSF and 1 out 9 with HTLV-II positive in serum and CSF), HIV-1 (1), Subacute combined sclerosis (6).

${ }^{\mathrm{c}}$ Pernicious anemia (1), multiple sclerosis (1), HIV-1 (3), cervical spine osteoarthropathy (2), Friedreich's ataxia (1), Spine-cerebellar degeneration (1), ALS (1)

' Tardive dyskinesia (1), Huntington's chorea (1).

${ }^{\mathrm{e}}$ Idiopathic epilepsies (11), Myasthenia gravis (1), Dermatomyositis (1).

311), respectively. HTLV-I serological results were independent of seropositivity for syphilis and HIV-1 infection. All patients with syphilis had negative VDRL in CSF.

Concerning therapy, although we advised treatment (prednisolone $1 \mathrm{mg} / \mathrm{kg} /$ day during three to six months) to severely affected patients, most of them were lost to follow up because they mostly came from remote and poorly medicalized places.

\section{Discussion}

The etiology of progressive spastic paraparesis without evidence of spinal cord compression has been less elusive in Brazil after the discovery that HTLV-I infection is endemic in several regions of the country.
In the present study the overall seroprevalence of HTLVI among patients with neurological disease was $20.9 \%$. However, this prevalence was $50 \%$ and $6.9 \%$ among patients with chronic myelophathy and other neurological diseases, respectively.

Thus, the finding of 50\% prevalence of HTLV-I associated with chronic myelophathy in our result is in agreement with a previous report in Salvador [16], as well as in Rio de Janeiro, in Southeast Brazil [21]. This prevalence is different from the $20.9 \%$ [22], 28.6\% [17] and the $27 \%$ [23] previously found in this city as well as the $14 \%$ reported in Recife Northeast Brazil [24]. These discrepancies in results could be due to different sampling selection, lack of stringency in clinical diagnosis and applied methodology for laboratory diagnosis.

This prevalence is similar to that one found in other tropical countries but different from those observed in 
Table 3

Summary of neurological involvement in 52 patients with HAM

\begin{tabular}{llc}
\hline Neurological dysfunction & No. of patients & $\%$ \\
\hline Psychological examination & 52 & 100 \\
Normal & & \\
Motricity of lower limbs & 52 & 100 \\
Weakness & 50 & 96.2 \\
Hyperreflexia patellar & 35 & 67.3 \\
Hyporreflexia achilleus & 37 & 71.2 \\
Spasticity & 38 & 73.1 \\
Babinski's sign & 15 & 28.8 \\
Atrophy of quadriceps & 26 & 50.0 \\
Cramps & & \\
Motricity of upper limbs & 10 & 19.2 \\
Weakness & 36 & 69.2 \\
Hyperreflexia & 30 & 57.7 \\
Hoffmann's sign & & \\
Sensitivity in lower limbs & 36 & 59.6 \\
Loss/reduction of superficial sensitivity & 31 & 51.9 \\
Loss/reduction of deep sensitivity & 27 & 30.8 \\
Impotence & 16 & 86.5 \\
Urinary urgence or incontinence & 45 & \\
Obstipation & 42 & \\
Back pain & 36 & \\
\hline
\end{tabular}

Japan [25]. Indeed, in that country a $100 \%$ prevalence of HAM/TSP has been observed because HAM by definition is always associated with HTLV-I. In addition, this fact can be also explained by the absence of other causes of chronic myelophathy not related to HTLV-I in Japan such as vitamin deficiencies, syphilis, schistosomiasis, cysticercosis, post infection and post vaccination myelophaties.

Moreover, we observed a clearly female predominance of HAM/TSP which increases with age. These data confirmed previous results in Salvador [16,23] and are in agreement with most other series studied, in other regions of our country [26]. The female predominance of HAM/ TSP cases may be directly related to the higher efficiency of male-to-female transmission than female-to-male transmission of HTLV-I [27].

The higher prevalence of HTLV-I antibodies in patients with neurological diseases other than chronic myelopathy (6.9\%) when compared to blood donors (1.35\%) [2] and pregnant women $(0.9 \%)$ [28] could be due to different ages among the groups studied. Indeed the large majority of blood donors, as well as pregnant women previously tested for HTLV-I antibodies in Salvador are younger who usually have a lower prevalence of HTLV-I infection even in areas with high endemicity. In our series, the majority (87\%) of the HTLV-I positive patients without chronic myelopathy were at an age higher than 40 years (data not shown), corroborating this hypothesis.

In a previous study carried out in Santo Antonio Hospital (the origin of half of the patients in the present study), [17] showed that $10 \%$ of the tuberculosis patients had HTLV-I antibodies. Similarly, in the present study, 2 out of 15 (13\%) HTLV-I infected patients without chronic myelopathy presented tuberculosis. Since tuberculosis is endemic in the city of Salvador, this fact could be related to the immunosupression caused by HTLV-I infection triggering reactivation of primary tuberculosis.

No association of blood transfusion, injecting drugs use or syphilis with HTLV-I infections was found in the present study. However, it seems that sexual transmission plays an important role in HTLV-I transmission in Salvador as it has been previously suggested [29]. Concerning syphilis our data are similar to those observed in Jamaica [30] and Gabon [31] where syphilis was not associated with HTLV-I infection. In Jamaica [30] the sexual transmission of HTLV-I seems to be associated with HAM/TSP and, in addition, it was observed, in Rio de Janeiro, Brazil an association of HAM/TSP with a prior history of sexually transmitted diseases [21]. Unfortunately, we did not investigate the history of sexually transmitted disease in our present study.

Despite several authors having described other neurological syndromes such as Guillain-Barré [11], CNS vasculitis [14], amyotrophic lateral sclerosis [10] and Parkinson's disease [9], associated with HTLV-I, the only clinical manifestation that showed statistical association to HTLV-I infection in Salvador, was myelopathy and myeloneuropathy. All the others seemed to be spurious.

The clinical picture of HAM/TSP in this study was similar to those described in different parts of the world $[4,5,32,33]$ as well as in other part of Brazil [26]. In the present study we observed $100 \%$ and $19.2 \%$ of weakness in lower and upper limbs, respectively showing a mainly involvement of thoracic spinal cord in our patients. This data suggests that this disease in Salvador is characterized by diffuse encephalomyeloneuropathy, mainly involving the thoracic spinal cord, also supported by MRI observations [34].

Contrary to what has been described in Japan [32], clinical peripheral neuropathy was found in $80.8 \%$ of our patients. These data confirmed previous reports in Guyana [35] and in Rio de Janeiro [36].

We conclude that, in our region, HTLV-I is the most important cause of myelopathies of obscure origin. HTLVII is not as important as a causative factor of neurological diseases, and the only neurological picture associated to HTLV-I is chronic myelopathy or myeloneuropathy.

\section{Acknowledgements}

This study was partially supported by the STD/AIDS, Ministry of Health, Brazil, Ministère Français des Affaires Etrangères and Brazilian National Research Council (CNPq). We thank Mr Noilson Gonçalves for technical assistance. 


\section{References}

[1] Mueller N. The epidemiology of HTLV-I infection. Cancer Causes and Control 1991;2:37-52.

[2] Galvão-Castro B, Loures L, Rodrigues LGM, Sereno A, Ferreira Jr OC, Franco LGP, Muller M, Sampaio DA, Santana A, Passos LM, Proietti F. Distribution of human T-lymphotropic virus type I among blood donors: a nationwide Brazilian study. Transfusion 1997;37:242.

[3] Spina-França A, Salum PNB, Limongi JCP, Berger A, Losso ER. Mielopatias: aspectos diagnósticos. Arq Neuro-Psiquiatr 1980;38:360-6.

[4] Gessain A, Barin F, Vernant JC, Gout O, Maurs L, Calender A, de Thé G. Antibodies to human T-lymphotropic virus type-I in patients with tropical spastic paraparesis. Lancet 1985;ii:407-9.

[5] Osame M, Usuku K, Izumo S, Ijichi N, Amitani H, Igata A, Matsumoto M, Tara M. HTLV-I associated myelopathy, a new clinical entity. Lancet 1986;i:1031-2.

[6] Castro-Costa CM, Carton H, Goubau P, D'Almeida. Brazilian studies on tropical spastic paraparesis. A meta-analysis. Arq Neuropsiquiatr 1994;52:585-591.

[7] Mochizuki M, Ono A, Ikeda E, Hikita N, Watanabe T, Yamaguchi K, Sagawa K, Ito K. HTLV-I uveitis. J Acquir Immune Defic Syndr Hum Retrovirol 1993;13(Suppl):S50-6.

[8] Komaba Y, Kitamura S, Terashi A, Tamotsu M, Nakatani Y, Hara A. Human T-cell lymphotropic virus type-I associated myelopathy complicated by optic neuritis. Nippon Ika Daigaku Zasshi 1996;63:414-8.

[9] De Freitas E, Saida T, Iwasaki Y, Koprowski E. Association of human T-lymphotropic virus in chronic neurological disease. Ann Neurol 1987;21:215-6.

[10] Ferrante P, Westarp ME, Mancuso R, Puricelli S, Westarp MP, Mini M, Caputo D, Zuffolato MR. HTLV tax-rex DNA and antibodies in idiopathic amyotrophic lateral sclerosis. J Neurol Sci 1995;129(Suppl.):140-4.

[11] Nakauchi CM, Linhares AC, Gomes MLC, Maruyama K, Kanzaki LI, Azevedo VN. Antibody to human T-lymphotropic virus in a patient with Guillain-Barré syndrome (case report). Rev Inst Med Trop São-Paulo 1991;33:329-31.

[12] Cupler EJ, Leon-Monzon M, Miller J, Semino-Mora C, Anderson TL, Dalakas MC. Inclusion body myositis in HIV-1 and HTLV-1 infected patients. Brain 1996;119:1887-93.

[13] Higuchi I, Hashimoto K, Matsuoka E, Rosales R, Nakagawa M, Arimura K, Izumo S, Osame M. The main HTLV-I-harboring cells in the muscles of viral carriers with polymyositis are not macrophages but CD4+ lymphocytes. Acta Neuropathol (Berl) 1996;92:358-61.

[14] Smith D, Lucas S, Jacewicz M. Multiple cerebral hemorrhages in HTLV-I-associated myelopathy. Neurology 1993;43:412-4.

[15] Reddy EP, Sandberg-Wollheim M, Mettus RV, Ray PE, De Freitas E, Koprowski H. Amplification and molecular cloning of HTLV-I from DNA of multiple sclerosis patients. Science 1989;243:529-33.

[16] Moreno-Carvalho OA, Santos JI, Di-Credico G, Galvão-Castro B. Evidence of preferential female prevalence of HTLV-I associated tropical spastic paraparesis in Bahia, Brazil. Arq Neuropsiquiatr 1992;50:183-8.

[17] Moreira Jr ED, Ribeiro TT, Swanson P, Sampaio-Filho C, Melo A, Brites C, Badaró $R$, Toedter $G$, Lee $H$, Harrington Jr W. Seroepidemiology of human T-cell lymphotropic virus type I/II in Northeastern Brazil. J Acquir Immunne Defic Syndr 1993;6:959-63.

[18] Azevedo ES, Fortuna CMM, Silva KMC, Sousa MGF, Machado MA, Lima AMVMD, Aguiar ME, Abe K, Eulalio MCMN, Conceição MM, Silva MCBG, Santos MG. Spread and diversity of human population in Bahia, Brazil. Hum Biol 1982;54:329-41.

[19] Krieger H, Morton NE, Mi MP, Azevedo ES, Freire-Maia A, Yasuda N. Racial admixture in Northeastern Brazil. Ann Hum Genet 1965;29:113-25.
[20] Moreno-Carvalho OA, Nascimento-Carvalho CMC, Galvão-Castro B. HTLV-I associated tropical spastic paraparesis: cerebral spinal fluid evolutive aspects in 128 cases. Arq Neuropsychiat 1995;55:604-7.

[21] Araujo AQ-C, Afonso CR, Schor D, Andrade-Serpa MJ. Spastic paraparesis of obscure origin. A case control study of HTLV positive and negative patients from Rio de Janeiro, Brazil. J Neurol Sci 1993;116:165-9.

[22] Meireles A, Moreira Jr ED, Moreno-Carvalho OA, Badaró R, Melo A. HTLV-I associated myelopathy in Salvador (Northeastern Brazil). Arq Neuropsiquiatr 1992;50:189-90.

[23] Andrade-Filho AS, Brites C, dos-Santos SRS, Harrington Jr W, Reinhardt ICB, Freitas FMS, Silva MC, Badaró R. HTLV-I/II as a common etiology of myelopathies in Bahia, Brazil. Braz J Med Biol Res 1996;29:757-61.

[24] Guedes T, Mesquita SD, Codeceira Jr A, Ataide Jr L, Silva AB. New cases of HTLV-I associated myelopathy in Northeast, Brazil. Neurobiologia (Recife) 1993;56:1-8.

[25] Zaninovic V. Is it tropical spastic paraparesis due to HTLV-I only. In: Zaninovic V, editor, HTLV Truths and Questions, Fundacion Mar Cali, Colombia, 1996.

[26] Araújo AQ-C, Andrada-Serpa MJ. Tropical spastic paraparesis/ HTLV-I-associated myelopathy in Brazil. J Acquir Immune Defic Syndr Hum Retrovirol 1996;13(Suppl.):S33-6.

[27] Murphy EL, Figueroa JP, Gibbs WN, Brathwaite A, Holding-Cobbam M, Waters D, Cratson B, Hanchard B, Blattner WA. Sexual transmission of human T-lymphotropic virus type I. Ann Intern Med 1989;111:550-60.

[28] DosSantos JI, Lopes MAA, Deliège-Vasoncelos E, Couto-Fernandez JC, Patel NB, Barreto ML, Ferreira Jr OC, Galvão-Castro B. Seroprevalence of HIV, HTLV-I/II and other perinatally-transmitted pathogens in Salvador, Bahia. Rev Inst Med Trop São Paulo 1995;37:343-8.

[29] Santos C, Sampaio E, Santana I, Galvão-Castro B, Castilho E, Loures L. Evidence for sexual transmission of HTLV I/II in Brazil $\mathrm{X}$ International Conference on AIDS. Yokohoma, Japan PC0600 August, 7-12, 1999.

[30] Kramer A, Maloney EM, Morgan OSC, Rodgers-Johnson P, Manns A, Murphy EL, Larsen S, Cranston B, Murphy J, Benichou J, Blattner WA. Risk factors and cofactors for human T-cell lymphotropic virus type I (HTLV-I) associated myelopathy/tropical spastic paraparesis (HAM/TSP) in Jamaica. Am J Epidemiol 1995;142:1212-20.

[31] LeHesran JY, Delaporte E, Gaudebout C, Trebuck A, Schrijvers D, Josse R, Peeters M, Cheringou H, Dupont A, Larouze B. Demographic factors associated with HTLV-I infection in a Gabonese Community. Int J Epidemiol 1994;23:812-7.

[32] Osame M, Igata A, Matsumoto M, Kohka M, Usuku K, Izumo S. HTLV-I-Associated Myelopathy (HAM). Treatment trials, retrospective survey and clinical and laboratory findings. Hematol Ver 1990;3:271-84.

[33] Gessain A, Gout O. Chronic myelopathy associated with human T-lymphotropic virus type I (HTLV-I). Ann Intern Med 1992;117:933-46.

[34] Melo A, Moura L, Rios S, Machado M, Costa G. Magnetic resonance imaging in HTLV-I associated myelopathy. Arq Neuropsiquiatr 1993;51:329-32.

[35] Said G, Goulon-Goeau C, Lacroix C, Feve A, Descamps H, Fouchard M. Inflammatory lesions of peripheral nerve in a patient with human T-lymphotropic virus type I associated myelopathy. Ann Neurol 1988;24:275-7.

[36] Nascimento OJM, Araujo AQ-C, Freitas MRG, Escada TM, Andrada-Serpa MJ. Peripheral nerve involvement in HTLV-I associated myelopathy. J Acquir Immune Defic Syndr Hum Retrovirol 1995; 10:230. 